\title{
Folklor w służbie komunizmu. Żart Milana Kundery w adaptacji Jaromila Jireša
}

Czescy prozaicy lat 60. porzucili rozprawianie się z mitem rewolucji (jak to miało miejsce w bodaj najsłynniejszej powieści poprzedniej dekady - Tchórzach Josefa Škoreckiego) na rzecz portretowania pokolenia, które, słowami Witolda Nawrockiego, , ,[...] w trudnych obrotach Historii utraciło autentyczność przeżyć, przyćmiło swą wrażliwość moralną, bunt zastąpiło oportunistycznym poddaniem lub trywialną grą" ${ }^{\prime 1}$. Niewątpliwie jednym z najwybitniejszych utworów wpisujących się w nurt rozliczeniowy z latami 50. jest Żart (wyd. czeskie 1967) Milana Kundery. W historii literatury czeskiej zazwyczaj umieszcza się go pomiędzy utworami takimi jak Sekyra (Siekiera, wyd. czeskie 1966) Ludvíka Vaculíka, Horečka (Goraczka, wyd. czeskie 1967) autorstwa więźnia politycznego Karela Pecki ${ }^{3}$, powieści Jiř́iego Muchy (Jaka będzie miat twarz $z^{4}$ wyd. czeskie 1963 oraz Studené slunce ${ }^{5}$, wyd. czeskie 1968) czy niezwykle interesujący, pod wieloma względami zbliżony do Żartu, Kręgostup (wydanie czeskie w 1963 r., polskie w 1966)

1 Witold Nawrocki, Josef Škvorecký: epik przeżyć pokoleniowych, [w:] Josef Škvorecký, Tchórze, tłum. Emilia Witwicka, Śląsk, Katowice 1964, s. 12-13.

2 Jeśli dany utwór - literacki lub filmowy - był wydany (dystrybuowany) w Polsce, podaje jego polski tytuł. W pozostałych przypadkach najpierw podaję tytuł oryginalny, a następnie proponowane polskie tłumaczenie.

3 Bohaterem powieść Karela Pecki Horečka (Goraczka) jest więzień polityczny, któremu udało się uciec z obozu pracy przymusowej. W latach 1967-1968 nad scenariuszem opartym na utworze Pecki pracował doświadczony twórca filmowy Ladislav Helge. Do realizacji projektu nie doszło wskutek wkroczenia wojsk Układu Warszawskiego. Zob. Jan Lukeš, Slovo nevezmu zpět. Nerealizované scénáre šedesátých let, „Iluminace” 1996, nr 1, s. 23-26.

4 Wydanie polskie ukazało się w 1968 r. Zob. Jiř́i Mucha, Jaka będzie miał twarz, tłum. Emilia Witwicka, PIW, Warszawa 1968.

5 Zimne słońce. 
Ladislava Bublíka ${ }^{6}$ W „prozie straconych złudzeń" ${ }^{\prime 7}$ - jak nazywa ten nurt autorka Historii literatury czeskiej, Zofia Tarajło-Lipowska - pojawiała się refleksja natury historiozoficznej dotycząca deterministycznej roli historii w życiu człowieka, powracał motyw rozczarowania erą kompulsywnego budowania socjalizmu i niesmak pozostały w związku z przyjęciem zachowań oportunistycznych, skrywaniem przez bohaterów własnych przekonań pod maską brzydkiej mimikry. Ową mieszankę złości na los oraz przekonania, że jednak w głównej mierze to od działań jednostki zależy jej przyszłość, wyraża pasaż z Jaka będzie miał twarz Jiříego Muchy:

Chciał zacisnać pięści, podnieść wzrok w górę i przeklinać, bluźnić czemuś, co miało nad nim władzę, co go opuściło i deptało po nim na oślep olbrzymią słoniową nogą. Ale nie było nic ani nad nim, ani dokoła niego. Był tylko on sam ${ }^{8}$.

Podobnie jak literaci, także filmowcy podjęli próbę opisania i przewartościowania doświadczeń związanych z latami 50. w Czechosłowacji ${ }^{9}$. Najważniejsze filmy plasujące się w tym nurcie to powstały na podstawie prozy Kundery: Żart (1968, prem. 1969) ${ }^{10}$ Jaromila Jireša, Smuteční slavnost (Uroczystość żałobna, 1969, prem. 1990) Zdenka Sirovego, Wszyscy dobrzy rodacy (1968, prem. 1969) Vojtěcha Jasnego, Skowronki na uwięzi (1969, prem. 1990) Jiř́iego Menzla oraz filmy Karela Kachyni: Noc nevěsty (Noc oblubienicy, 1967), Směšný pán (Śmieszny pan, 1969) oraz Ucho (1970, prem. 1990). Nieprzypadkowo wiele z nich powstało w latach 1968-1970 - to właśnie

6 Akcja powieści odgrywa się w 1951 r. na terenie budowy kombinatu hutniczego w Kunčicach koło Ostrawy. Głównym bohaterem jest jeden z więźniów przymusowo pracujących na „pierwszej budowie socjalizmu” w Czechosłowacji. Zob. Ladislav Bublík, Kręgostup. Z dziennika nieznanego brygadzisty, tłum. Edward Madany, Czytelnik, Warszawa 1966. W 1965 r. powieść Bublíka została sfilmowana przez Vladimíra Čecha i weszła do dystrybucji pod tytułem Úplně vyř́zený chlap (Wykończony człowiek).

7 Zob. Zofia Tarajło-Lipowska, Historia literatury czeskiej. Zarys, Zakład Narodowy im. Ossolińskich - Wydawnictwo, Wrocław 2010, s. 350-353.

8 Jiří Mucha, dz. cyt, s. 317.

9 O czeskich filmach rozrachunkowych dotyczących lat 50. powstałych po 1989 r. piszę w artykule: Stalin i big-beat. Medialne rekonstrukcje lat 50. XX wieku we wspótczesnym kinie czeskim, [w:] Przeszłość we współczesnej narracji kulturowej, t. 3: Studia i szkice kulturoznawcze, red. Piotr Biliński, Paweł Plichta, Wyd. Uniwersytetu Jagiellońskiego, Kraków 2012, s. 133-154.

10 Daty ukończenia filmów i ich premier podaję za: Český hraný film IV, 1961-1970. Czech Feature Film IV, 1961-1970, red. Eva Urbanová, Blažena Urgošiková, Národní filmový archv, Praha 2004. Jeżeli przy filmie pojawia się tylko data, oznacza to, że rok produkcji i premiery były tożsame. 
ożywcza atmosfera Praskiej Wiosny umożliwiła „przebicie” się odważnych scenariuszy i umożliwiła ich realizację.

Niestety, „braterska interwencja” w sierpniu 1968 r. i stopniowe wycofywanie się państwa z wywalczonych obietnic liberalizacji spowodowały wyłączenie tych filmów z dystrybucji jako niezgodnych z linią partii. W przypadku wielu tytułów miało miejsce „zablokowanie” ich rozpowszechniania jeszcze przed oficjalną premierą. Niektórym z nich, mimo krótkiego czasu dystrybucji, udało się zaistnieć w świadomości rodzimych i zagranicznych widzów, inne żyły w anegdocie, jeszcze inne w ogóle nie pojawiły się w świadomości społecznej.

\section{Żart na tle twórczości Jaromila Jireša}

Żart Jaromila Jireša chronologicznie jest drugim filmem absolwenta FAMU (kierunek operatorski i reżyseria). Jireš zwrócił na siebie uwagę pracami realizowanymi w ramach studiów; w dokumencie Horečka (Goraczka, 1958) w rytm jazzowej muzyki obrazował eskalację społecznego napięcia, oczekiwanie w kolejkach na... nowy numer czasopisma "Večerní Praha”. W 1960 r. Jireš ukończył wydział operatorski absolwenckim filmem Sál ztracených kroků (Sala zagubionych kroków), sytuującym się na pograniczu filmu fabularnego i dokumentalnego. Właśnie Sál ztracených kroků ugruntowała pozycję Jireša jako największego eksperymentatora wśród ówczesnych studentów FAMU. Krokiem w stronę kina realistycznego był film, którym Jireš formalnie ukończył studia na kierunku reżyserii: Stopy (Ślady, 1960). Nowela ta, wraz z filmami Zdenka Sirovego i Hynka Bočana, także opartymi na opowiadaniach z tomu Niema barykada Jana Drdy, była wyświetlana w kinach pod wspólnym tytułem Hlídač dynamitu (Strażnik dynamitu) dopiero zimą $1963 \mathrm{r.}^{11}$

Pełnometrażowym debiutem Jireša był Pierwszy krzyk (Křik) zrealizowany w studiu Barrandov w roku 1963 (prem. 1964), do którego scenariusz napisał wspólnie z prozaikiem Ludvíkiem Aškenazym. Pod względem zastosowanych środków filmowych oraz formy opowiadania jest to jeden z najbardziej interesujących filmów powstałych w Czechosłowacji na początku lat 60. Rejestrowanie nieinscenizowanej rzeczywistości, skupienie się na wewnętrznym świecie bohaterów, satyryczne spojrzenie na prażan, a jednocześnie szukanie poezji w przeżyciach dnia codziennego

11 Jan Jaroš, Jaromil Jireš, ČFú, Praha 1990, s. 5.

12 W Polsce funkcjonuje także tłumaczenie tego tytułu jako Krzyk. 
- to najważniejsze cechy Pierwszego krzyku. W 1965 r. na łamach „Filmu” Stanisław Grzelecki pisał:

\begin{abstract}
Wrażliwość Jireša jest przede wszystkim wrażliwością widzenia, wspomaganą czułością kamery. Wprowadzeni w strumień potocznych wydarzeń, nie możemy właściwie dokonywać wyboru - wchłaniamy wszystko, co się wokół dzieje, tkwimy w życiu, jako jego organiczna cząstka - ciałko krwi krążące w organizmie zbiorowości. W tym chyba, w tej niejako biologicznej bezpośredniości, tkwi najbardziej charakterystyczna cecha filmu Pierwszy krzyk ${ }^{13}$.
\end{abstract}

Niestety, wbrew intencji autora, film został wykorzystany do celów propagandowych: reżimowi krytycy przeciwstawiali go, ich zdaniem przesadnie pesymistycznemu i promującemu czarnowidztwo, filmowi Evalda Schorma Odwaga na co dzień (1964, prem. 1965). Po tym niemiłym doświadczeniu Jireš celowo szukał możliwości zrealizowania pełnometrażowego filmu, którego odbiór nie mógłby zostać w ten sposób zmanipulowany. W 1965 r. zrealizował nowelę Romanca, opowiadającą o miłości młodego elektryka do cygańskiej dziewczyny; opowieść ta weszła w skład opartych na prozie Bohumila Hrabala Pereł na dnie (1965). W czasie pomiędzy debiutem Pierwszy krzyk (1963) a Żartem (1968) Jaromil Jireš realizował dokumenty, które, zdaniem czeskiego krytyka Jana Lukeša, można traktować jako preludia czy też wstępne szkice do Żartu ${ }^{14}$. Wśród bogatego dorobku dokumentalnego na szczególną uwagę zasługują: pochodząca z 1967 r. Hra na krále (Zabawa w króla), w której autor obrazował przygotowania i przebieg corocznej Jazdy Królów - temat ten, głęboko przetworzony i pozbawiony obecnego tu jeszcze liryzmu, odnajdziemy potem w Żarcie. Zrealizował także film Dédáček (Dziadek, 1968) oraz Cesta do Prahy Vincence Moštka a Šimona Pešla z Vlčnova I. p. 1969 (Wyprawa Vincenza Moštka i Šimona Pešla z Vlčnova do Pragi A.D. 1969) - w tym drugim przypadku współreżyserem był operator wszystkich krótkich filmów Jireša, Vladimír Skalský. W wymienionych filmach Jireš sportretował starych mieszkańców Moraw. Drugi nurt twórczości dokumentalnej Jireša to filmy Občan Karel Havliček (Obywatel Karel Havliček, 1966) oraz zrealizowany już po Żarcie Tribunál (Trybunat, 1969). Pierwszy z nich był rekonstrukcją procesu, w którym brał udział XIX-wieczny publicysta i urzędnik Karel Havlíček

13 Stanisław Grzelecki, Dzień oczekiwania (recenzja), „Film” 1965, nr 24, s. 4.

14 Jan Lukeš, O (ne) smyslu destrukcí, [w:] tenże, Orgie střídmosti aneb Konec československé státní kinematografie (kritický deník 1987-1993), Národní filmový archiv, Praha 1993, s. 168. 
Borovský, oskarżony o ośmieszanie obowiązującego prawa. Bohater bronił się oświadczeniem, że krytykował nie tyle złe prawo, co nieudolnych i niekompetentnych urzędników. Dla wszystkich uczestników zainscenizowanego przez Jireša procesu było jasne, że bezkompromisowa postawa Borovskiego także dzisiaj spotkałaby się z potępieniem. Film Tribunál także jest rekonstrukcją, tym razem z posiedzenia komisji, która w 1952 r. zakazała publicznego eksponowania dzieł malarza Emila Filly z powodu ich wyraźnego odstępstwa od norm wyznaczanych przez doktrynę realizmu socjalistycznego. W swoim filmie Jireš ukazuje inspirowane ludowymi przyśpiewkami obrazy Filly, które przez członków komisji uznane zostały za "formalistyczne".

\section{Od prozy Kundery do filmu Jireša}

Powieść Kundery jest umieszczana przez krytyków w nurcie literatury rozrachunkowej, będącej jednocześnie świadectwem osobistych zmagań autorów, którzy w młodzieńczej naiwności powitali komunizm z otwartymi ramionami (Kundera przez krótki okres należał do Komunistycznej Partii Czechosłowacji). Ówcześni czytelnicy i komentatorzy docenili walory demaskatorskie utworu, w którym autor dokonuje pogłębionej analizy i krytyki mechanizmów stalinowskiego totalitaryzmu oraz śledzi, w jaki sposób dawne zbrodnie systemu rzutują na dzisiejsze życie bohaterów. Sam autor widział w Żarcie utwór o bardzo uniwersalnej wymowie: „Powróciłem na chwilę do lat pięćdziesiątych nie dlatego, aby ujawniać jakieś sensacyjne fakty historyczne, ani by malować obraz epoki. Lata pięćdziesiąte pociągały mnie dlatego, że historia dokonywała wówczas niesłychanych eksperymentów z człowiekiem, że poprzez niepowtarzalne sytuacje ukazywała go w nowym świetle i wzbogaciła w ten sposób moją wiedzę o tym, czym jest człowiek i ludzki los"15.

Tekst powieści Kundery ukończony był już 5 grudnia 1965 r. Jeszcze zanim ukazała się w formie książkowej, na jej podstawie w 1966 r. Milan Kundera, Jaromil Jireš i dramaturg Zdeněk Bláha napisali scenariusz do planowanego filmu. Zgodę na realizację otrzymano w styczniu 1968 r., tuż po tym, jak przebiegły zmiany na kierowniczych stanowiskach w Komunistycznej Partii Czechosłowacji. Żart, podobnie jak Wszyscy dobrzy rodacy

15 Antonín J. Liehm, Generace (rozmowa z Milanem Kunderą), Československý spisovatel, Praha 1990, s. 63 (tłum. własne). 
Vojtěcha Jasnego, w pierwotnym zamyśle miał być realizowany w $1969 \mathrm{r}$. - jednakże kierownictwo Studia Filmowego Barrandov postanowiło niezwłocznie wykorzystać sprzyjające okoliczności polegające na rozluźnieniu kursu w partii (a co za tym idzie - w podlegających jej przedsiębiorstwach) i oba filmy zostały przesunięte do planu produkcyjnego na $1968 \mathrm{r}^{16}$

Co ciekawe, realizacja zdjęć w Pradze przypadła dokładnie w drugiej połowie sierpnia 1968 r., kiedy to gąsienice czołgów „bratnich” krajów rozjeżdżały bruk na placu Wacława ${ }^{17}$. Premiera Żartu miała miejsce 28 lutego 1969 r. Paradoksalnie, film znalazł się na ekranach, gdy znów każdy żart był podejrzany, bo przecież wesoły może być $i$ nihilista [...] może na przykład śmiać się z ludzi, którzy cierpia. Wesoły może być i cynik ${ }^{18}$, który niestosownie dworuje sobie $\mathrm{z}$ dominującej ideologii, obowiązujących zasad, dyscypliny i optymizmu. W sierpniu 1971 r. Żart został wycofany z dystrybucji. Do tego czasu film obejrzało ponad 300 tysięcy widzów ${ }^{19}$. Jak pisze czeski historyk filmu Jan Lukeš: „Żart z Żartem nie opłacił się ani Kunderze, ani Jirešowi: pierwszy został zmuszony do emigracji (gdzie owszem jako pisarz zyskał międzynarodowe uznanie), drugi poprzez schlebianie gustom filmowych decydentów na długi czas zgubił sam siebie"20. Podobną opinię wyraził Josef Škvorecký, który, głównie w kontekście niezrealizowanych w latach 60. projektów Jireša, nazwał go „największym pechowcem Nowej Fali”"21. W kolejnych dwóch dekadach

16 Żart został wpisany do planu produkcyjnego na 1968 r. zamiast filmu Legenda o krásné Julince przygotowywanego przez Ivana Passera, który to został przesunięty na następny rok. Film ostatecznie nie został zrealizowany, 9 stycznia 1969 r. Ivan Passer wyemigrował do Nowego Jorku. Štěpán Hulík, Kinematografie zapomnění. Počátky normalizace ve filmovém studiu Barrandov (1968-1973), Academia, Praha 2012, s. 41.

$17 \mathrm{Z}$ tego powodu scena prokomunistycznej manifestacji została nakręcona nie w centrum miasta - co mogłoby zostać odczytane jako prowokacja - ale na terenie Barrandova, przed wejściem do sali zdjęciowej nr 5. Nie oznacza to jednak, że nie obyło się bez problemów: studenci zatrudnieni jako statyści nie chcieli krzyczeć „Niech żyje Związek Radziecki". Po długich negocjacjach ekipie udało się uzyskać zaplanowany efekt. Berta Štenclová, About the making of the movie "Joke”, www.praha.eu/jnp/en/extra/Year_68/ film/about_the_making_of_the_movie_joke_html (dostęp: 13.07.2012).

18 Milan Kundera, Żart, tłum. Emilia Witwicka, PIW, Warszawa 1991, s. 27.

19 Jan Lukeš, O (ne) smyslu destrukcí..., s. 167.

20 Jan Lukeš, dz. cyt., s. 168.

21 Škvorecký wspomina o pracy Jireša z Arnoštem Lustigiem nad scenariuszem dotyczącym więźniów Pomocniczych Batalionów Pracy (na podstawie noweli Lustiga) oraz o projekcie Jireša i Karela Michala pod tytułem Azurové vodopády, dotykającym narodzin nazizmu. Zob. Josef Škvorecký, Všichni ti bystří muži a ženy, [w:] tenże, Nejdražší umění a jiné eseje o filmu. Spisy 37, Books and Cards, Praha 2010, s. 135-138 (tekst pochodzi z 1971 r.). 
Jireš pracował w studiu Barrandov głównie nad propagandowymi projektami, nie udało mu się powrócić do artystycznego poziomu reprezentowanego przez Pierwszy krzyk czy Żart ${ }^{22}$.

\section{Zabiegi adaptacyjne}

Filmowy Żart w znacznym stopniu odbiega od książkowej wersji utworu Kundery. Powieść posiada o wiele bardziej skomplikowaną strukturę: naprzemiennie rolę pierwszoosobowego narratora odgrywają cztery osoby: Ludvík Jahn, Helena Zemánková, Jaroslav - dawny przyjaciel Ludvíka z rodzinnej miejscowości - oraz ewangelik Kostka ${ }^{23}$. W filmie pominięty został szeroko opisany w książce wątek związany z postacią Łucji, którą z Ludvíkiem, przebywającym wówczas w koszarach w Ostrawie, łączyła „szara miłość". Film, w porównaniu z książką, daje nam także o wiele mniej informacji na temat przeszłości Kostki, który po odejściu z uczelni przez kilka lat pracował w gospodarstwie rolnym - tam właśnie spotkał Łucję, następnie był zatrudniony jako pracownik fizyczny, by dzięki staraniom Ludvíka uzyskać posadę laboranta w ostrawskim szpitalu.

W filmie na plan pierwszy została wysunięta postać Ludvíka Jahna, on także jako jedyny pełni funkcję narratora opowieści. W ten sposób, poprzez ograniczenie postaci pierwszoplanowych, filmowy Żart stał się w większej mierze portretem jednostki niż całego społeczeństwa, choć jednocześnie nie można odmówić dziełu Jireša ambicji komentowania kondycji całej powojennej generacji. Ze względu na liczne różnice pomiędzy książką a filmem pojawiły się stwierdzenia, że dzieło Jireša nie przekazuje obecnego w powieści rozmachu i intelektualnej głębi. Pisano, że o ile Żart Kundery jest lustrem, to Żart Jireša stanowi jedynie jego fragment ${ }^{24}$. Opinie te nie są jednak w stanie zdyskredytować wartości

22 W latach 70. i 80. Jireš realizował głównie filmy będące laurkami wobec nowej władzy, m.in. I pozdrawiam jaskółki (1972) o pobycie w więzieniu komunistycznej działaczki Marušky Kudeř́kovej (w tej roli Magda Vášáryová) czy Lidé z metra (Ludzie z metra, 1974) o budowniczych praskiego metra. W filmografii Jireša po roku 1968 na specjalne miejsce zasługuje film oparty na prozie Vítězslava Nezvala Waleria i tydzień cudów (1970), niepokojący obraz budzącej się dziewczęcej seksualności oraz realizacje, których scenariusze powstały na podstawie prozy Vladimíra Párala: Mladý muž a bílá verlyba (Młody mężczyzna i Moby Dick, 1978), Katapult (Katapulta, 1983), Recepta na życie (1984).

${ }_{23}$ W polskim przekładzie książki nazwiska bohaterów brzmią: Ludwik Jahn, Helena Zemankova, Jarosław, Kostka.

24 Panorama českého filmu, red. Luboš Ptáček, Rubico, Olomouc 2000, s. 256. 
filmu. Pomimo wprowadzonych zmian i uproszczeń względem książki, adaptacja sygnowana nazwiskiem Jireša stanowi mistrzowski przykład przeniesienia prozy Kundery na ekran kinowy.

Na marginesie warto zauważyć, że Kundera, podobnie jak Bohumil Hrabal, miał szczęście do adaptatorów swojej prozy: zarówno Nikt się nie będzie śmiat Hynka Bočana (1965, prem. 1966), Ja, smutny Bóg (1969) Antonína Kachlíka ${ }^{25}$, jak i Żart Jireša to znakomite filmy, które zachowują kluczowe walory pisarstwa Kundery ${ }^{26}$. Trzy pierwsze tytuły to adaptacje opowiadań ze zbioru Śmieszne miłości. Kundera współpracował przy tworzeniu scenariusza do filmu Ja, smutny Bóg Kachlíka. Nikt się nie będzie śmiał Bočana (scenariusz napisał Pavel Juráček) i Żart Jireša odniosły wielki sukces artystyczny, który tym mocniej ugruntował pozycję Kundery jako czołowego prozaika młodego pokolenia. Warto też wspomnieć o późniejszej, amerykańskiej adaptacji książki Kundery Nieznośna lekkość bytu w reżyserii Philipa Kaufmana (1988).

Na kilka słów komentarza zasługuje sposób prowadzenia filmowej narracji. Ewa Graczyk analizując twórczość Kundery, zauważyła, że u czeskiego pisarza: „,[...] czas nie płynie, raczej skacze, porusza się z mniejszymi czy większymi drgnieniami, małymi «trzęsieniami ziemi»" ${ }^{\prime 2}$. Cytat ów w bardzo trafny sposób oddaje także styl filmu Jireša. Został w nim zachowany podstawowy rys prozy Kundery, w której narracja nie jest prowadzona w sposób linearny, ale opiera się na ciągu asocjacji i skojarzeń. Aktualne wydarzenia prowokują powrót do minionych sytuacji. Filmowy Żart powtarza także tę cechę pisarstwa Milana Kundery, która polega na tym,

25 W Polsce znanej także pod tytułem Teoria uwodzenia. Badacz Mircea Dan Duta określa film Kachlíka mianem „zapomnianego” dziecka czechosłowackiej Nowej Fali. Kachlík przed realizacją Teorii uwodzenia, a także potem, hołdował narracji przejętej z XIX-wiecznej powieści. Jako człowiek zawsze stał po stronie oficjalnej polityki, dopuszczał się kompromisów w życiu społecznym i artystycznym. Jednakże, zdaniem rumuńskiego autora, przeoczenie Teorii uwodzenia jako przykładu dzieła Nowej Fali byłoby wielką szkodą dla historii czeskiej kinematografii i kultury w ogóle. Adaptacja noweli Milana Kundery ze zbioru Śmieszne miłości jego zdaniem zasługuje na uwagę ze względu na niezwykłą nowatorskość stylistyczna, a także tematyczną. Dan Duta widzi szczególną wartość filmu Kachlíka w relatywizowaniu ról widza, reżysera i autora. Por. M. D. Duta, Naratologické perspektivy a nárativní techniky v české Nové vlně v 60. letech, rozprawa doktorska napisana pod kierownictwem Zdeny Škapovej w Wydziale Telewizji i Filmu Wyższej Szkoły Artystycznej w Pradze (FAMU), 2004.

26 W latach 60. powstały dwa studenckie filmy oparte na prozie Milana Kundery, oba w reżyserii Jana Davida: Na shledanou (Do widzenia, 1967) oraz Eduard a Bůh (Edward i Bóg, 1969).

27 Ewa Graczyk, Porcja Kundery, [w:] taż, O Gombrowiczu, Kunderze, Grassie i innych ważnych sprawach. Eseje, Marabut, Gdańsk 1994, s. 57. 
że retrospekcje nie pojawiają się $\mathrm{w}$ porządku powtarzającym rzeczywiste następstwo wydarzeń. Dla przykładu, pierwsza filmowa retrospekcja przenosi nas o tydzień wstecz, następnie powracamy do studenckich czasów bohatera, obserwujemy Ludvíka podczas pobytu w wojsku, aby ponownie ujrzeć fragmenty pochodów z okresu studiów bohatera. Przeplatanie się wymiarów czasowych następuje także w ścieżce dźwiękowej filmu: podczas sceny przyjmowania dzieci w poczet obywateli socjalistycznej Czechosłowacji słyszymy głosy członków komisji, która przesłuchiwała Ludvíka.

W interesujący sposób zostało rozwiązane zagadnienie obecności bohatera w scenach retrospektywnych. Wbrew oczekiwaniom, młodego Ludvíka nie odgrywa inny aktor. Przez długi czas sylwetka Jozefa Somra w ogóle nie pojawia się w kadrze (pochody pierwszomajowe, spotkania z Małgorzatą, sąd na uniwersytecie). Zanim ujrzymy Ludvíka, oglądamy epizody z jego biografii widziane okiem subiektywnej kamery, przedstawiającej świat widziany właśnie przez bohatera. Zabieg subiektywizacji widzenia został wzmocniony poprzez konsekwentne zwracanie się rozmówców Ludvíka bezpośrednio w stronę kamery, tak jakby właśnie tam znajdował się ich interlokutor. Samego bohatera zauważamy dopiero w scenach przedstawiających jego przymusowy pobyt w wojsku.

Skąd decyzja o ukazaniu samej postaci Ludvíka dopiero od momentu służby wojskowej? Można przypuszczać, że poprzez ten zabieg reżyser pragnął uwypuklić niedojrzałość bohatera, który dopiero w sytuacji realnego zagrożenia życia i godności ludzkiej zrozumiał prawdziwe konsekwencje płynące z nadużywania władzy i zgubne skutki bezmyślnego przestrzegania dogmatów ideologii komunistycznej. Nie oznacza to jednak, że owo traumatyczne doświadczenie „wyleczyło” go z kolejnej fazy niedojrzałości, jaką było rozpamiętywanie swoich krzywd i zaciekłe pielęgnowanie nienawiści względem swoich oprawców. Owo „zatrzymanie się" Ludvíka na pewnym etapie rozwoju intelektualnego i psychicznego sugeruje zabieg identyczności wyglądu bohatera z czasów pobytu w wojsku i czasów współczesnych. Ludvík ma tę samą fryzurę, tę samą posturę, ten sam wyraz twarzy co ponad dziesięć lat wcześniej.

Na uwagę zasługuje także kompozycja filmowych kadrów. Cechuje ją asymetria oraz tendencja do eksponowania nieznaczących, zdawałoby się, przestrzeni. I tak, w scenie przyjazdu Ludvíka do miasteczka autobus, z którego wysiadają pasażerowie, znajduje się w lewej górnej części kadru, podczas gdy pozostałą przestrzeń stanowi kostka brukowa, pokrywająca nawierzchnię w miasteczku. Operator Jan Čuř́ík unikał planów pełnych oraz panoram; w Żarcie przeważają plany amerykańskie i zbliżenia, szczególnie często widzimy twarz Ludvíka Jahna. 
Na komentarz zasługują decyzje dotyczące obsady filmu. Znaczący jest fakt, że w rolę Kostki wcielił się w filmie reżyser i okazjonalny aktor Evald Schorm, który ze względu na moralizatorski ton swoich filmów nazywany był "sumieniem Nowej Fali”. Podobny typ postaci, jak Kostka, Schorm stworzył w filmie O uroczystości i gościach (1966, reż. Jan Němec), gdzie wcielił się $\mathrm{w}$ rolę Męża, który odmawia uczestniczenia w urodzinach prominenta. Pojawienie się Schorma w roli ewangelika Kostki poprzez odwołanie do artystycznej postawy tego reżysera, a także wcześniejszych ról niewątpliwie przydało tej postaci dodatkowego wymiaru. Także Helena, bohaterka stworzona przez Janę Dítětova, dzięki kontekstowi wcześniejszych postaci odgrywanych przez tę aktorkę - były to głównie natchnione komunistyczne działaczki - zyskała dodatkowy wymiar. Wedle zamiarów Jireša w postać Zemánka miał się wcielić poeta i prozaik Pavel Kohout, który jednak odrzucił tę propozycję. Na jego miejsce zaangażowany został Luděk Munzar, dla którego była to, obok roli rannego niemieckiego żołnierza Günthera w Wozie do Wiednia Karela Kachyni, najważniejsza kreacja aktorska stworzona w latach 60. I wreszcie odtwórca głównej roli, Ludvík Somr. Dla niego także, mimo kilku pierwszoplanowych ról odegranych w tym okresie, występ w filmie Jireša zaowocował najbardziej wyrazistą kreacją w całej karierze aktorskiej.

\section{Folklor zniewolony}

W Żarcie spotkały się dwie główne linie tematyczne widoczne w dokumentach realizowanych przez Jireša: zainteresowanie sytuacją człowieka postawionego oko w oko z represyjnym systemem (Občan Karel Havličck, Tribunál) oraz żywa troska o kulturę ludową Moraw, a w szczególności regionu Słowacko (Hra na krále, Dědáček) ${ }^{28}$. Warto zauważyć, że analogiczne wątki - sympatia względem folkloru morawskiego, fascynacja ludową muzyką tego regionu - będą się także pojawiać w późniejszej twórczości tego reżysera ${ }^{29}$. Ze względu na wagę owych zagadnień dla Jireša i Kundery zasadne będzie przyjrzenie się książce oraz filmowi przez przyzmat ideologicznego problemu wykorzystywania kultury ludowej przez komunizm ${ }^{30}$.

28 Jan Jaroš, dz. cyt., s. 12.

29 M.in. w filmach: Opera ve vinici (Opera w winnicy, 1981), Lev s bílou hř́vou (Lew z biała grzywa, 1986), Zápisník zmizelého (Pamiętnik zaginionego, film TV, 1979), Po zarostlém hodničku (Po zarośniętej ścieżce, dok., 1987). Zob. Miloš Zapletal, Zdeněk Pololáník a Žert (Několík marginálií k filmové hudbě), „Film a doba” 57, 2011, nr 2-3, s. 72.

30 Tożsame zagadnienie podejmuje zrealizowany w $1963 \mathrm{r}$. absolwencki film średniometrażowy autorstwa Karela Vachka pod tytułem Moravská Hellas. 
Żart zawiera głęboką refleksję na temat sposobów i skutków „zagospodarowania ludowych tradycji artystycznych"31, czyli wykorzystania kultury ludowej w służbie socjalizmu, co zarówno w dziele Kundery, jak i Jireša przybiera ostra, oskarżycielską formę rozliczenia z systemem komunistycznym. W Czechosłowacji, podobnie jak w PRL-u, kultura ludowa miała tworzyć podstawy tożsamości kultury narodowej, być jej fundamentem, gwarancją jedności, a zarazem nadawać jej niepodważalną indywidualność. Ów program zwięźle ujmuje hasło: „tradycja ludowa własnością narodową ${ }^{\prime \prime 32}$. Jednocześnie kultura ludowa traktowana była bardzo wybiórczo: jedne elementy były akceptowane przez władzę komunistyczną, inne nie. Nastąpiło oderwanie obrzędowości od naturalnego środowiska. Należało wykazać, że dawni artyści, także ludowi, w sposób intuicyjny dążyli do tych samych celów, które wówczas realizowała władza komunistyczna ${ }^{33}$. Oczywiście były też i takie dzieła, które w żaden sposób nie poddawały się nowej interpretacji - te wykluczano z życia kulturalnego, skazując na zapomnienie.

Proces wprowadzania w okresie stalinowskim wybranych składników kultury chłopskiej do kultury narodowej, głównie w postaci przetworzonej, Józef Burszta nazywa folkloryzmem ${ }^{34}$. Charakteryzując to zjawisko, autor pisze o celowych, specjalnie aranżowanych przekazach artystycznych tradycji ludowych we współczesności. Cechowały je teatralizacja, dekoratywność, komercjalizacja. Forma widowisk folklorystycznych stanowiła w PRL-u rodzaj dekoracji, świątecznej oprawy różnego typu uroczystości, takich jak Dożynki, Cepeliada, święta „Trybuny Ludu” i „Trybuny Robotniczej”, a nawet święto 1 Maja $^{35}$.

31 Określenia tego używa Józef Burszta. Zob. tenże, Chłopskie źródła kultury, Ludowa Spółdzielnia Wydawnicza, Warszawa 1985, s. 291.

32 Jest to jeden z tytułów rozdziału książki Józefa Burszty, Chłopskie źródła..., s. 292.

33 Grzegorz Pełczyński ukazuje, w jaki sposób w polskich filmach Jasne łany (1947) Eugeniusza Cękalskiego, Młodość Chopina (1951) Aleksandra Forda i Warszawska premiera (1950) Jana Rybkowskiego dokonana została nowa, „słuszna” interpretacja dzieł kultury polskiej. Pierwszym z nich przejął wątek z noweli Janko Muzykant Sienkiewicza, z tym, że został on zwieńczony happy endem. Dwa ostatnie filmy, opowiadając o klasykach polskiej muzyki, poniekąd uzasadniają ich ważność w kulturze ludowej. Grzegorz Pełczyński, Dziesiąta muza w stroju ludowym. O wizerunkach kultury chłopskiej w kinie PRL, Wyd. Naukowe UAM, Poznań 2002, s. 41-44.

34 Józef Burszta, Folkloryzm, [w:] Słownik etnologiczny. Terminy ogólne, red. nauk. Zofia Staszczak, PWN, Warszawa-Poznań 1987, s. 131-132.

35 Izolda Topp, Od przeżytku do zabytku. Szkic do obrazu kultury ludowej w PRL-u, [w:] Nim będzie zapomniana. Szkice o kulturze PRL-u, red. Stefan Bednarek, Wyd. Uniwersytetu Wrocławskiego, Wrocław 1997, s. 129. 
Analiza filmowego wątku Żartu związanego z Jazdą Królów (o samym obrzędzie - za chwilę) dowodzi adekwatności opisu Burszty wobec diagnozy Jireša i Kundery. Czescy autorzy bardzo wyraźnie zaznaczyli w swoim dziele wszystkie elementy, które składają się na pojęcie folkloryzmu. Co ciekawe, sam termin pojawił się dopiero w latach 60. XX w., równocześnie $\mathrm{w}$ wielu krajach europejskich ${ }^{36}$; można więc powiedzieć, że filmowy i literacki Żart były artystyczną formą wyrażenia treści, które w tym samym czasie zaprzątały głowę badaczy kultury ludowej, nie tylko w Czechosłowacji.

W latach 90. XX w. inny badacz, Wojciech J. Burszta ${ }^{37}$, sformułował tezę, że kultura ludowa wkracza w fazę postfolklorystyczną. Ta ewolucja została już przewidziana na przełomie lat 60. i 70., kiedy zauważono społeczne tendencje zmierzające do stworzenia narodowej jedności folklorystycznej, do połączenia wszystkich warstw narodu pod sztandarem folkloru narodowego. Burszta akcentuje jeszcze jedną ważną cechę postfolkloryzmu: „Folklor poszczególnych regionów etnograficznych staje się z wolna przede wszystkim znakiem folkloru narodowego, wyrazem zewnętrznej, sztucznej, skonwencjonalizowanej «ludowości patriotycznej»»38.

Żart akcentuje obecność także tego typu przemian. Kultura ludowa regionu Moraw, jako najbardziej barwna i dynamiczna, służy tutaj jako znak ogólnej ludowej kultury Czechosłowacji. Mieszkańcy Moraw zawsze odczuwali pewną odrębność od mieszkańców Czech (nazwa Czechy przyjęła się w języku polskim dla całego państwa czeskiego, choć w rzeczywistości Czechy są tylko jego częścią), która wyrażała się nie w poczuciu odrębności tożsamości narodowej czy w używaniu języka literackiego, lecz w różnicach w kulturze ludowej, stylu życia i gwarze ${ }^{39}$. Morawianie zawsze byli lojalni wobec Czechów. Antagonizmy pojawiły się dopiero po powstaniu Czechosłowacji, na zasadzie występującego także w innych krajach zjawiska niechęci prowincji do stolicy. Przekonanie o jej eksploatowaniu przez Czechów w dobie komunizmu nie mogło być wyartykułowane, natomiast dało o sobie znać po Aksamitnej Rewolucji. Trudno ocenić, na ile ilustrowany przez Kunderę i Jireša proces promowania kultury ludowej regionu Moraw był wyrazem świadomego dążenia władzy komunistycznej do

36 Józef Burszta, Folkloryzm..., s. 131-132.

37 Wojciech J. Burszta, Wymiary antropologicznego poznania kultury, Wyd. Naukowe UAM, Poznań 1992, s. 207.

38 Tamże, s. 210.

39 Tadeusz Siwek, Morawianie, „Sprawy Narodowościowe. Seria nowa” 2002, z. 20, s. 127. W skład Moraw wchodzą następujące regiony: hanacki (Haná) z ośrodkiem w Ołomuńcu, wałaski (Valašsko), horacki (Horácko), laski (Lašsko) i morawsko-słowacki (Moravské Slovácko), gdzie rozgrywa się akcja Żartu. 
zacierania antagonizmów pomiędzy Czechami a Morawianami poprzez akcentowanie swoistej wyższości czy atrakcyjności ludowych zwyczajów Moraw. Tym niemniej to właśnie zwyczaje i tradycje tego regionu - z których wiele jest żywych do dzisiejszego dnia, włączając w to opisaną przez Kunderę Jazdę Królów, odbywającą się do dziś w miejscowości Vlčnov stały w się w Żarcie znakiem „patriotycznej ludowości” Czechosłowacji. Żart ukazuje zgubne skutki sterowania kulturą ludową która pod wpływem impulsów ze strony komunistycznych ideologów przekształciła się w martwy twór. Autorów interesują głównie przekształcenia w obrębie kultury muzycznej oraz obrzędowości ludowej (Jazda Królów). Utwór Kundery i Jireša, traktowany jako dzieło dokonujące rozliczenia z czasami stalinizmu, jest w tym sensie przede wszystkim gorzką oceną tego, co władza uczyniła z folklorem, a więc starą tradycją. Poczynając od wątku związanego z Jazdą Królów, chciałabym się przyjrzeć, w jaki sposób Kundera i Jireš ustosunkowują się do tego problemu.

Ludvík powraca do rodzinnego miasteczka w dniu, gdy ma się odbyć coroczna Jazda Królów. W książce Kundery, który sam brał udział w tego typu uroczystości, znajdujemy szczegółowy opis wydarzenia, a także rozważania na temat jego korzeni i wymowy:

Kiedy pobity król węgierski Maciej uciekał z Czech na Węgry, jego konnica musiała go tutaj na terenie Moraw ukrywać przed czeskim pościgiem i żebranina zdobywać żywność dla siebie i dla niego. Mówiono, że Jazda Królów urządzana jest na pamiątę tego historycznego zdarzenia, ale starczyło pogrzebać trochę w starych dokumentach, żeby stwierdzić, że uroczystość Jazdy Królów jest dużo starsza niż wspomniana historia. Skąd się wzięła i co oznacza? Czy może jeszcze pochodzi z czasów pogańskich i jest pamiątka obrzędów, w czasie których chłopak przechodzit pod opiekę ojca i stawat się mężczyzną? I dlaczego król i jego paziowie maja na sobie kobiece suknie? Czy to obraz tego, jak niegdyś jakaś wojenna drużyna (obojętnie czy króla Macieja, czy jakaś o wiele dawniejsza) wiodła swego władcę w przebraniu przez kraj wroga, czy też sa to relikty jakiegoś pogańskiego zabobonu, wedle którego przebranie chroni przed złymi duchami? Ale dlaczego królowi przez cały czas nie wolno odezwać się ani słowem? I czemu ów obrzęd nosi nazwę Jazdy Królów, skoro jest w nim tylko jeden król? Co to wszystko znaczy? Nie wiadomo. Istnieje wiele hipotez, ale żadna nie została udowodniona. Jazda Królów jest obrzędem tajemniczym; nikt nie wie, co właściwie oznacza, co ma wyrażać, ale tak jak hieroglify egipskie piękniejsze sa dla tych, którzy nie potrafia ich odczytać ( $i$ widza w nich tylko fantastyczne rysunki), tak Jazda Królów dlatego jest tak piękna, że sens jej wymowy dawno się zatracit i tym mocniej wysuwaja się na czoło gesty, barwy, słowa, skupiając cała uwage na sobie, na wtasnym ksztatcie i formie ${ }^{40}$.

W filmie Jireša, podobnie jak w książce Kundery, Jazda Królów jest świętem odartym z całego blasku i tajemnicy; ludowy obrzęd, niegdyś

40 Milan Kundera, Żart, s. 192-193. 
będący autentyczną ekspresją wierzeń miejscowej ludności, przemienił się w kiczowaty spektakl. Nikt już nie pamięta, jakie są źródła Jazdy Królów; co więcej, nikogo to zdaje się nie interesować. Takie epitety, jak tajemniczość, niejednoznaczność, zagadkowość, zdają się nie pasować do opisu święta, które obecnie jest także, a może przede wszystkim, spektaklem komunistycznej władzy.

Jazda Królów jest jedynie pretekstem do wypitki i rozróby. Smutny obraz święta rysują ujęcia przedstawiające stojące na rynku wysokie ławy, zapewne wypożyczone na czas święta $\mathrm{z}$ baru samoobsługowego, pomiędzy którymi na wietrze tańczą papiery i puste kubki. Jeźdźcy na koniach muszą lawirować pomiędzy ryczącymi samochodami. Obecnie Jazda Królów

[...] to trochę kicz, a trochę jarmarczna maskarada. Serca z pierników na piersiach koni! Tony zakupionych hurtem papierowych wstażek! Dawniej stroje regionalne były także barwne, ale prostsze. Konie byly przyozdabiane tylko jedna czerwona chustka, która wiazano im pod szyja przez pierś. Nawet król nie miał maski z kolorowych wzorzystych wstązek, tylko ze zwykłej chusteczki. Za to miat jeszcze różę w ustach. Żeby nie mógł mówić. Nie było w Jeździe Królów nic z cyrku. Była baśniowa ${ }^{41}$.

Jazda Królów nie pełni swojej dawnej roli: nie jednoczy mieszkańców we wspólnym przeżywaniu tajemniczego święta. Ostro zostały oddzielone funkcje widza i uczestnika. Jazda Królów stała się wyreżyserowanym spektaklem, w którym wszystko dzieje się „na niby”, na sposób umowny. Józef Burszta, pisząc o folklorze festiwalowym, którym niewątpliwie jest Jazda Królów, zauważa, że to właśnie w nim nastąpiło „[...] ścisłe oddzielenie wykonawcy-aktora od uczestnika-widza. Komunikacja treściowa płynie tylko w jednym kierunku, a kontekst sytuacyjny funkcjonowania tych treści jest już zupełnie inny od tradycyjnego ${ }^{\prime \prime 2}$.

Dzisiejsza Jazda Królów to spektakl zorganizowany specjalnie dla turystów, takich jak Zemánek czy towarzysząca mu studentka. O stopniu komercjalizacji najlepiej świadczy fakt, że pojawiły się nawet figurki z miniaturowymi jeźdźcami, które prawdopodobnie można zakupić jako pamiątkę (jedną z takich zabawek zauważamy na biurku recepcjonisty pracującego w hotelu, w którym zatrzymał się Ludvík).

Znakiem wskazującym na oderwanie corocznej parady od jej naturalnego kontekstu jest informacja, że tegoroczna Jazda Królów nie odbyłaby się bez pomocy kółka rolniczego, które zgodziło się wypożyczyć w tym

\footnotetext{
41 Tamże, s. 196.

42 Józef Burszta, Chłopskie źródła..., s. 307.
} 
celu konie. Organizacja obrzędu nie jest inicjatywą ludzi, którzy w ten sposób chcieliby zamanifestować swoje przeżywanie kultury, ale odgórnym nakazem.

Jazda Królów, która niegdyś ożywiała i jednoczyła mieszkańców miejscowości, wydaje się obecnie pustym obrzędem. Na początku pochód ludzi ubranych w regionalne stroje wzbudza zainteresowanie mieszkańców, którzy machając zielonymi gałązkami, witają nowego króla. Ale wkrótce uwaga widzów zwraca się w stronę innych atrakcji: straganów z watą cukrową, stoiska $\mathrm{z}$ alkoholami. Przejazd barwnego pochodu, stanowiący sedno Jazdy Królów, jest tylko jednym z punktów programu tego święta: konkurencję dla niego stanowią m.in. występy gimnastyczne zorganizowane przez lokalny klub sportowy.

Wśród wiwatujących ludzi jest sporo przyjezdnych. Są tam Pavel Zemánek i towarzysząca mu dziewczyna, którzy wpadli tu w drodze powrotnej z Bratysławy, gdzie Zemánek miał wykład. Ani Zemánek, ani studentka nie wydają się przesadnie zainteresowani Jazdą Królów. Dziewczyna pije śliwowicę, którą zza płotu częstuje ją kobieta, je watę cukrową i familiarnie obejmuje swojego profesora. Twierdzi, że cała parada byłaby ciekawsza, gdyby udało się spłoszyć konie. Dla Zemánka i jego towarzyszki Jazda Królów jest jedynie barwnym festynem, kolorowym pochodem. Żadne z nich nie widzi i nie chce widzieć w tej lokalnej tradycji wyrazu jakichś autentycznych pragnień, nie interesuje ich tkwiąca w Jeździe Królów tajemnica. Święto jest dla nich lokalną atrakcją; być może uznają, że to kolejna upolityczniona maskarada, jakich wiele w życiu widzieli.

Oczywiście, źródła obojętności Zemánka i jego studentki względem Jazdy Królów są całkowicie różne. Bohaterka należy do pokolenia, które wykładowca charakteryzuje w następujący sposób: Dzisiejsi dwudziestolatkowie sa zupetnie inni niż my byliśmy. My cała młodość przesiedzieliśmy na zebraniach, a oni sobie podróżuja. My chcieliśmy zbawić świat, a oni troszcza się tylko o siebie. Dzięki temu moga uratować świat. Postawa studentki wobec Jazdy Królów wynika z generalnej niechęci do wszelkich społecznych wyrazów zaangażowania. Z drugiej zaś strony, jej zachowanie jest wyrazem uprzedzenia, ale przede wszystkim obojętności wobec strywializowanej przez ustrój ludowości. Folklor, zaprzęgnięty w służbę ideologii komunistycznej, stracił całą swoją siłę i autentyczność. Nic dziwnego, że młodzież, radykalnie odcinająca się od trącącego myszką świata ojców, zanegowała także sensowność i wagę kultywowania tradycji ludowych, tak hołubionych przez piewców komunistycznej ideologii. Rzec można, że kultura ludowa stała się kozłem ofiarnym systemu. Na niej skupiła się niechęć młodych ludzi. We wszystkich dziedzinach życia 
zaczęto odcinać się od ludowości, ponieważ komunizm, wykorzystując lokalne tradycje i zwyczaje dla umacniania własnych dogmatów, skompromitował rzekomą „,swojskość". Nagle nie do pomyślenia stało się, aby młodzi ludzie ubierali regionalne stroje i tańczyli morawskie tańce. Na scenie muzycznej zatriumfował jazz, twist i rock and roll. Muzyka ludowa niemal zupełnie zniknęła z realnego życia, a także z twórczości filmowej. W filmie Formana Konkurs (1963, prem. 1964) żadna z dziesiątek dziewcząt, pretendujących do posady śpiewaczki w Semaforze, nie zaprezentowała ludowej piosenki; w pierwszym czeskim musicalu Starcy na chmielu (1964, reż. Ladislav Rychman), choć akcja rozgrywa się na prowincji, bohaterowie tańczą jazz i bossa novę. W powieści Żart pochodzący z Moraw lokalny muzyk następująco opisuje owo zetknięcie się dwóch światów:

\begin{abstract}
Byłem niedawno w Pradze i poszedłem do jednego z tych małych teatrzyków, które w latach sześćdziesiatych zaczęty wyrastać jak grzyby po deszczu i bardzo szybko zyskaty sobie popularność, ponieważ kierowali nimi młodzi ludzie nadający im studencki styl. Grano jakąś sztukę o nienadzwyczajnej akcji, ale były tam dowcipne piosenki i dobry jazz. Nagle, ni stad, ni zowad, ci jazzowi muzykanci wsadzili sobie na głowę kapelusze z piórkiem, takie, jakie nosi się u nas do strojów regionalnych, i zaczęli naśladować wiejska kapele. Pokrzykiwali, pohukiwali, naśladując nasze ruchy w tańcu i to nasze charakterystyczne wyrzucanie ręki w górę... Trwato to chyba nie więcej niż pięć minut, ale publiczność pokładała się ze śmiechu. Nie wierzyłem własnym oczom. Jeszcze pięć lat temu nikt nie odważyłby się z nas naigrywać. I nikt by się $z$ tego nie śmiat. A teraz wzbudzamy śmiech. Jak to się stało, że nagle wzbudzamy śmiech? ${ }^{43}$
\end{abstract}

W książce Kundery najwyraźniej owa niechęć młodzieży do tradycji ojców spuentowana została w zachowaniu syna Jaroslava, który zamiast zostać Królem i tym samym oddać należny szacunek ojcu, po kryjomu pojechał na zawody motocyklowe do Brna. W filmie Jireša problem ten ilustruje konfrontacja muzyków z ludowej kapeli ze słuchaczami, wśród których przeważała głośna, arogancko zachowująca się młodzież.

Pozytywny obraz ówczesnych dwudziestolatków rysowany przez Zemánka, który brak zaangażowania uważa za największą zaletę swoich studentów, nie znajduje odzwierciedlenia w filmowych wizerunkach młodych ludzi. Obraz młodych w Żarcie nie wypada pochlebnie: studentka towarzysząca Zemánkowi interesuje się jedynie śliwowicą i konsumpcją waty cukrowej, chłopcy i dziewczyny pijący w knajpie zachowują się głośno i wulgarnie, syn Jaroslava ponad wszystko przedkłada szybkie motocykle. Portret młodego pokolenia według Kundery i Jireša zbliża się do diagnozy postawionej w Stokrotkach (1966) Věry Chytilovej. Tam także

\footnotetext{
43 Milan Kundera, Żart, s. 97.
} 
włada niepohamowana konsumpcja, beztroska zabawa, a także zamiłowanie do destrukcji. Studentka z Żartu, niewątpliwie zafascynowana „profesorem", traktuje go w instrumentalny sposób, widząc w nim sponsora, będącego w stanie zapewnić oczekiwane atrakcje: zabrać w podróż, kupić jedzenie. Podobnie jak bohaterki Stokrotek, niecierpliwie oczekuje jakichś nadzwyczajnych wydarzeń: Jazda Królów wydaje jej się nudna; aby ubarwić pochód, próbuje przynajmniej spłoszyć konie. Studentka Jireša i dwie Marie Chytilovej są świadome swojego atrakcyjnego wyglądu i bez skrupułów wykorzystują walory urody oraz wieku, by osiągnąć upragnione cele. To, do czego dążą młode bohaterki Żartu i Stokrotek, także okazuje się zaskakująco bliskie: dziewczętom zależy bowiem przede wszystkim na dobrej zabawie i rozrywce, które utożsamiają z konsumpcją oraz destrukcją. Zachowanie to można odczytywać jako bezczelne i niemoralne, ale jest ono całkowicie wytłumaczalne, jeżeli działania dziewcząt odczytamy jako bunt przeciwko dogmatom poprzedniego ustroju. Wstrzemięźliwość, pracowitość, skromność, celowość zostają zastąpione rozpasaniem, lenistwem, wyuzdaniem oraz bezmyślnością.

Młodych ludzi według Kundery i Jireša cechuje obojętność, gruboskórność i brak altruizmu. [...] tłum młodzieży, wulgarnej, cynicznej i złej, wyzutej z entuzjazmu i ideałów, gotowej od pierwszego spotkania spótkować i zabijać się nawzajem ${ }^{44}$ - tak charakteryzuje w literackim Zarcie wchodzących w dorosłość obywateli Kostka. Młodzi nie są czyści i nieskażeni, lecz raczej puści, głupi i bez ideałów. Są interesowni i potrafią swoje walory przekuwać w wymierne korzyści materialne. Mają nową muzykę, nowe tańce, nowe stroje i fryzury. Ale nie czyni ich to bardziej wolnymi, świadomymi, lepszymi. Są tak samo zaślepieni jak ich ojcowie. Słowa Heleny, którymi opisuje ona atmosferę panującą w zespole - Wszyscy śpiewaliśmy - można potraktować jako metaforę ograniczenia i niewiedzy, które cechowały zarówno dawną, jak i dzisiejszą młodzież. Stosunek Pavla Zemánka do studentów cechuje wyrozumiałość, być może pobłażliwość, ale i fascynacja. Nie można jednak wykluczyć, że jego miłość do młodzieży wypływa jedynie z samolubstwa, pragnienia poklasku i pewnego wyrachowania: w końcu to przychylność młodych jest gwarantem jego pozycji na uniwersytecie (studenci go kochaja - mówi jego młoda przyjaciółka) oraz pozwala mu brylować w towarzystwie.

Ale nie tylko młodzi podchodzą z rezerwą do tradycji ludowych Czech i Moraw. Sceptycyzm cechuje zarówno zachowanie Zemánka, jak i Ludvíka. Obydwaj w czasie studiów entuzjastycznie podchodzili do idei kultywowania lokalnych zachowań, tańców, tradycji. Pod koniec lat 40.

44 Tamże, s. 196. 
i na początku lat 50. [...] było w wielkiej modzie śpiewać pieśni ludowe, i to śpiewać je nie na sposób szkolny, ale z ręka nad głowa i trochę prostackim głosem, i mieć przy tym minę autentycznego człowieka z ludu, którego matka powiła na jakiejś wiejskiej zabawie przy dźwięku cymbałów $w^{45}$ - z ironią wspominał narrator Kunderowskiego Żartu.

Główny bohater filmu - Ludvík - od dzieciństwa był zanurzony w lokalnej kulturze Moraw. W jednej z pierwszych scen, po przybyciu do miasteczka, widzi on na pustej ulicy małego chłopca na koniu. Status ontyczny tej sceny nie jest jasny, lecz podejrzewamy, że może to być jedynie wizualizacja wspomnienia $\mathrm{z}$ dzieciństwa, kiedy to i Ludvík brał udział w Jeździe Królów. Wizerunek chłopca tchnie majestatycznością, spokojem i pięknem. Tak musiała się niegdyś prezentować Jazda, zarówno w oczach widzów, jak i uczestników.

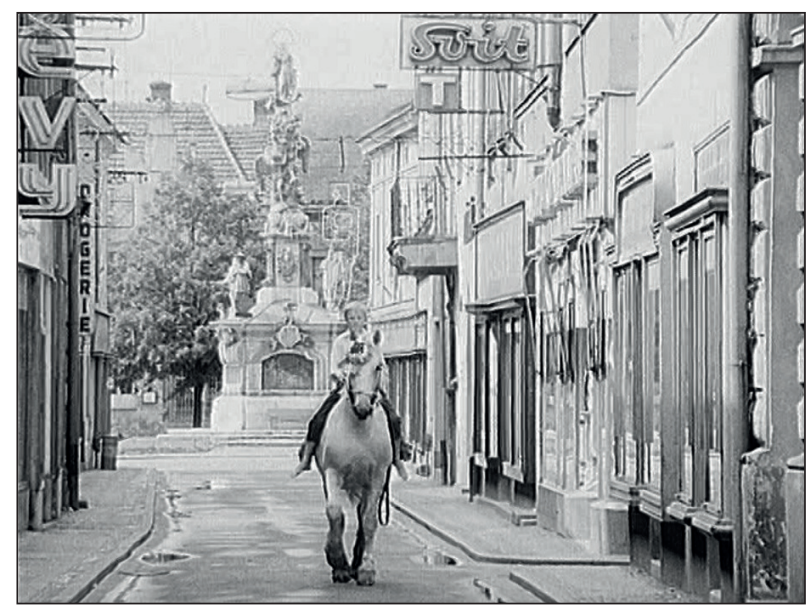

Fot. 5. Żart (1968, reż. Jaromil Jireš)

Oniryczny jeździec

Treść rozmowy Ludvíka z Jarosławem zdradza, że Jahn grał niegdyś w ludowej kapeli na klarnecie. Retrospekcje z czasów studenckich ukazują roztańczone, rozentuzjazmowane tłumy młodych ludzi, ubranych w lokalne stroje - prawdopodobnie był wśród nich także muzykujący Ludvík. W literackim Żarcie Kundera pisze, że Ludvík był jedynym prawdziwym Słowakiem (tj. osobą pochodzącą z regionu Moraw noszącego nazwę Słowacko) na całym wydziale, co dawało mu pewne przywileje:

\footnotetext{
45 Tamże, s. 29.
} 
[...] przy każdej uroczystej okazji, a nawet w czasie niektórych zebrań, obchodów czy na Pierwszego Maja, chłopcy zachęcali mnie, żebym wyciagną klarnet $i$ wraz z dwoma czy trzema amatorami spośród naszych kolegów imitował stowacka kapelę. Tak więc (z klarnetem, skrzypcami $i$ basetla) maszerowaliśmy przez dwa lata z rzędu w majowym pochodzie, a Zemanek, jako że ładny byt z niego chtopak i lubit się popisywać, szedt razem z nami, ubrany w wypożyczony strój regionalny, tańczył w pochodzie, wyrzucat rękę w górę i śpiewał. Ten rodowity prażanin, który na Słowacku nigdy nie byt, strasznie lubił udawać wiejskiego zawadiakę, a ja patrzyłem na niego życzliwie, bo byłem szczęśliwy, że muzyka moich rodzinnych stron, które od dawna stanowity eldorado sztuki ludowej, cieszy się taka sympatia ${ }^{46}$.

Jak już zaznaczyłam, partia z chęcią posługiwała się sztafażem ludowości, aby podkreślać związek myśli komunistycznej z odwiecznymi dążeniami i pragnieniami ludu, których ekspresją miał być właśnie folklor. Nawet Ludvík zdawał się wierzyć w owe szczytne idee, cieszył się, że muzyka ludowa zdobyła tak szerokie rzesze sympatyków ${ }^{47}$. Jednakże jego późniejsze doświadczenia z pobytu w koszarach, więzieniu i kopalni całkowicie zmieniły jego stosunek względem „regulowanego" folkloru. Bardzo trafnie jego obecną ocenę ilustrują sceny w urzędzie miejskim oraz w gospodzie, w której przysłuchuje się on próbie kapeli dyrygowanej przez Jaroslava. Bohater, zwabiony urodą młodej dziewczyny, trafia na salę urzędu miejskiego, gdzie odbywają się „ś́wieckie chrzty”, czyli powitanie nowych członków społeczeństwa. Absurdalnej ceremonii akompaniują ludowi muzycy, wśród nich jest Jaroslav. Z wyrazu jego twarzy możemy wyczytać, że owe występy traktuje jako niemiły obowiązek. Zażenowany Ludvík unika kontaktu wzrokowego z Jaroslavem, odczuwa żałosną komiczność całej sytuacji. Po ceremonii bohater zostaje zaproszony na próbę ludowego zespołu. Ludvík zostaje przedstawiony pozostałym muzykom. Dawny przyjaciel przypomina, że niegdyś wspólnie uczestniczyli w Jeździe Królów. Zachwala go jako rewelacyjnego klarnecistę i podkreśla, że to właśnie z Ludvíkiem zakładał ów zespół. Muzycy zaczynają próbę. Ludvík słucha. Muzyka nie przywołuje wspomnień z pracy w zespole, nie umożliwia nostalgicznego powrotu do dzieciństwa spędzonego

46 Tamże, s. 29-30.

47 W literackim Żarcie Ludvík został sportretowany jako osoba, która w swej studenckiej młodości świadomie wykorzystywała siłę i popularność folkloru dla umocnienia wiodącej roli partii i pozyskania dla niej nowych zwolenników. Jego „partiocentryzm” kazał mu traktować kontrolę nad kulturą ludową jako równie ważne zadanie jak nacjonalizacja czy kolektywizacja. Więcej na ten temat zob.: P. Karagyozov, The Intimate Jokes of "Partocentrism" in Milan Kundera's "The Joke" and Anchee Min's "Wild Ginger", "Acta Slavica Iaponica", t. 25, s. 163-186, www.ceeol.com/aspx/getdocument.aspx?logid=5\&id=9744B09C-0AC7-418C-8838-45B623CC0BFD (dostęp: 3.03.2009). 
na morawskiej prowincji. Ludvík przenosi się myślami do okresu, kiedy pracował w kamieniołomie. Dźwięki melodii, niejednokrotnie rozbrzmiewających podczas pochodów i oficjalnych uroczystości, w jego umyśle na zawsze splotły się z ustrojem, któremu Ludvík zawdzięczał sześć lat spędzonych w warunkach uwłaczających ludzkiej godności. Nienawiść do komunizmu przeniosła się na niechęć do wszystkiego, co było z nim związane. Muzyka, która rozbrzmiewała z megafonów, tańce, które tańczyli tak obłudni ludzie jak Zemánek, stały się dla Ludvíka odrażające. Nienawiść, która trawi wnętrze Ludvíka, odnosi się nie tylko do konkretnych osób, lecz obejmuje całość jego dawnych doświadczeń. Zdaje się, jakby Ludvík przeklinał nie tylko tych, którzy go skrzywdzili, ale wypierał się całego przeszłego życia, które w jego odczuciu od początku było skażone kłamstwem. O ile u Heleny Zemánkovej wspomnienie uczestnictwa w pracach zespołu muzyczno-tanecznego wywołuje błogi uśmiech na twarzy, to na informację, że dziennikarka tańczyła w zespole ludowym, oblicze Ludvíka wykrzywia grymas.

Jeszcze jedna scena w dobitny sposób puentuje stosunek Ludvíka do muzyki ludowej wykorzystywanej w służbie nowego ustroju. Podczas zbliżenia miłosnego z Heleną bohater przenosi się do czasów studenckich i widzi Zemánka w stroju ludowym tańczącego i śpiewającego piosenkę ze słowami: dnes je heslo mladí, ku předu a nikdy zpět (dziś obowiąuje młodość, idźmy do przodu, nigdy do tyłu). Ów wizualny komentarz podkreśla ironiczną wymowę samego aktu seksualnego, który jest równie wykalkulowany i sztuczny, jak rzekomo ludowe pieśni śpiewane przez rzekomych chłopów. Z drugiej zaś strony, przywołanie ludowej melodii w scenie "nie-miłosnej” (na pytanie Kostki, co to była za miłość, Ludvík odpowiada, że to była nie-miłość), w momencie przeżywania aktu zemsty, świadczy o kompletniej degradacji ludowości, która przecież niegdyś była dla bohatera azylem i świętością, a obecnie jest równie skompromitowana, jak wszystkie inne aspekty życia w socjalistycznym społeczeństwie.

Kundera w swojej książce na kilkunastu stronach przedstawia, jakimi motywami kierowali się admiratorzy folkloru, godząc się na przeinaczanie zawartych w pieśniach tekstów, upraszczanie linii melodycznej, rezygnację ze zwyczajowo przyjętych form prezentacji muzyki ludowej. Uważano, że jest to poświęcenie konieczne w imię przyszłości, w której prawdziwa sztuka ludowa (na razie jednak podawana w bardziej "przystępnej" formie) wyprze bezduszna szmire, która burżuje karmia lud ${ }^{48}$. Muzyka ludowa, podobnie jak zrobił to jazz, miała zespolić się z dzisiejszym życiem i rozwijać się razem z nim. Jaki to miało związek z socjalizmem?

48 Milan Kundera, Żart, s. 106. 
To nowy ustrój przywrócił kolektyw, a dzięki temu zagwarantował żywotność pieśni ludowej, która organicznie była związana z rytuałami i obrzędami cechującymi życie każdej wspólnoty. Socjalizm stworzył nową wspólnotę i w celu zagwarantowania jej trwania ożywił z przeszłości dawne zwyczaje, a także stworzył całkiem nowe, w których mogła rozwijać się sztuka ludowa.

\begin{abstract}
Stowianie niosa rewolucję. A wraz z nia nowa wspólnotę i nowe braterstwo, nowa sztukę, która będzie żyć w ludzie i z ludem, tak jak niegdyśs stare wiejskie piosenki [...]. Nikt nie zrobit dla naszej sztuki tyle, co władza komunistyczna - mówi w Kunderowskim Żarcie Jaroslav. - Ofiarowała ogromne kwoty pieniężne na tworzenie nowych zespołów. Muzyka ludowa, skrzypce i cymbaty rozbrzmiewaty codziennie w radiu. Fala morawskich $i$ słowackich pieśni ludowych wtargnęła do uniwersytetów, obchodów pierwszomajowych, na młodzieżowe zabawy $i$ estrady. Jazz nie tylko że zniknąt całkowicie z powierzchni naszego życia, ale stał się symbolem zachodniego kapitalizmu i jego upadku. Młodzi ludzie przestali tańczyć tanga $i$ boogie-woogie, a na swoich wieczorkach $i$ uroczystościach obejmowali się za ramiona $i$ tańczyli w kole tańce zbiorowe. Partia komunistyczna starała się stworzyć nowy styl życia. Tak jak w Zwiazku Radzieckim. Za podstawe brata stynna stalinowska definicje nowej sztuki: "socjalistyczna treść w narodowej formie". Tej narodowej formy nie mogło dostarczyć naszej muzyce, tańcowi, poezji nic oprócz właśnie sztuki ludowej ${ }^{49}$.
\end{abstract}

Bohater nienawidzi folkloru, który „zaprzedał się” w służbie komunizmu. Nienawidzi ludzi, którzy - najczęściej nieświadomie i w imię jak najbardziej chlubnych intencji - doprowadzili do degradacji znaczenia muzyki ludowej. Odstręczające wydają mu się pisane do ludowych melodii nowe teksty, jak jeden z tych, które śpiewa kapela Jaroslava: dobrze, że już nie ma nad nami pana. Ludvík nie mógł przebaczyć, że Jaroslav, w imię upowszechniania folkloru, zgodził się na „,kastrację" muzyki Moraw, polegającą na uproszczeniu linii melodycznej, a także ochoczo podjął się zadania pisania „ludowych" pieśni, sławiących rzeczywistość socjalistycznej Czechosłowacji. Jaroslav przeszedł drogę od czystego umiłowania folkloru do wymuszonego gloryfikowania partii poprzez folklor - czas pokazał, że komunistom wcale nie leżał na sercu rozwój prawdziwej kultury ludowej, a raczej chodziło im o stworzenie swoistej wersji pop-folkloru, muzyki łatwej w odbiorze i zgodniej w wymowie z linią polityczną partii. Jednocześnie Ludvík zazdrości Jaroslavowi, że ten wciąż może grać w zespole, że może odczuwać piękno ludowej muzyki. Bowiem tylko ona, jak ukazuje to scena wieczornego koncertu, może stanowić ucieczkę od złych myśli50. To właśnie podczas wspólnego występu Ludvík po raz

49 Tamże, s. 109.

50 Wspólne muzykowanie, jako potencjalna odtrutka na wszechobecne kłamstwo, zachowawczość i egoizm to także wątek Intymnego oświetlenia (1966) Ivana Passera. Dawni 
pierwszy w całym filmie ma pogodną twarz. Nie szpeci jej żaden grymas. Bohater wydaje się zrelaksowany i zadowolony. Owa chwila nie trwa długo; wkrótce koncert muzyków zagłuszają hałasy pijących alkohol wyrostków, rażony atakiem serca Jaroslav osuwa się na ziemię. Koncert zostaje przerwany. Sparaliżowany muzyk prawdopodobnie nie powróci już do gry w zespole; to był jego ostatni występ. Obojętność, pogarda, zapomnienie - tak rysuje się finał losów człowieka, który całe swoje życie poświęcił muzyce ludowej.

Wyrazem jeszcze innego stosunku do folkloru jest postawa Heleny Zemánkovej. Bohaterka w młodości śpiewała i tańczyła w ludowym zespole - z tym wiążą się jej najlepsze wspomnienia. Nie zdaje sobie sprawy z tego, że to właśnie dla takich niezbyt wymagających konsumentów jak ona prawdziwa sztuka ludowa została okaleczona. Helena wydaje się przesadnie podekscytowana atmosferą ludowego święta. Wiemy, że jej uwielbienie dla prostoty i ludowości jest czystą pozą i afektacją. Helena z nieukrywaną radością ubiera ludowy strój, który otrzymała w prezencie. Jest zachwycona jego krojem, gładzi koronki, w zdobionej koszuli czuje się niczym modelka na wybiegu. Zachowuje się tak, jakby ów strój był jakimś egzotycznym kostiumem, który udało jej się otrzymać „od tubylców". Helena wydaje się idealnym odbiorcą stworzonych na pokaz świąt i reaktywowanych tradycji. Jest konsumentką reglamentowanej przez komunizm kultury ludowej. Zna ją jedynie w okaleczonej, uproszczonej formie. Helena nie jest złą osobą: ale jej naiwność i brak krytycznego myślenia spowodowały, że nie była w stanie dostrzec fałszu kryjącego się za pozornie płynącą „,z ludu”, a w rzeczywistości sterowaną przez ideologów komunistycznych, muzyką ludową. Sztuka, nie tylko ludowa, prezentowana w uproszczonej formie, w jaskrawy sposób wypaczyła jej zmysł estetyczny. Helena, przyzwyczajona do odbioru sztuki, której wymowa jest jasna, optymistyczna i nieskomplikowana, w stojącej w miasteczku bogato zdobionej figurze (prawdopodobnie jest to słup morowy) widzi jedynie ciemną mistykę, pozbawioną radości życia.

Pavel Zemánek, podobnie jak towarzysząca mu studentka, wobec Jazdy Królów zachowuje daleko idącą obojętność. Nie wypiera się, że niegdyś sam brał udział w maskaradach, stylizowanych na ludowe święta.

przyjaciele z konserwatorium, Petr i Karel, po całym dniu pełnym drobnych niepowodzeń i nietaktownych zachowań, zbliżają się do siebie przy butelce śliwowicy i dźwiękach muzyki. Decydują się, że rzucą swoje zakłamane życia i pójdą w świat grać piękną muzykę. Jako że dość szybko dopada ich zmęczenie, decydują się pojechać autem. Niestety, zamiast ruszyć, zasypiają wewnątrz wozu. 
Przyznaje, że w dniu 1 Maja zakładał ludowy strój. I to właśnie on, a nie Ludvík, dobitnie puentuje rolę folkloru w życiu ludzi ówczesnej Czechosłowacji: Wszystkie te pochody, pieśni, wiwaty to byt parawan, za którym zamykano, skazywano i dokonywano egzekucji na niewinnych ludziach. Żyliśmy w więzieniu, gdzie na balkonach przygrywała orkiestra. Stwierdzeniu Zemánka nie można odmówić trafności. Jednocześnie pojawia się wątpliwość, czy bohater mówi tak, bo jest oburzony tym, co działo się w przeszłości, czy może po prostu postępuje zgodnie $\mathrm{z}$ obowiązującym obecnie kursem, który nakazuje krytykować czas stalinizmu i składać hołd wszystkiemu, co młode, niezaangażowane i nowoczesne, czyli nieludowe? Zemánek-kameleon wie, w jakim czasie należy ubrać jaki strój - niegdyś nosił haftowaną koszulę, dzisiaj marynarkę, przeciwsłoneczne okulary i czarny golf.

Ostatnia z pierwszoplanowych postaci, Kostka, w ogóle nie pojawia się na Jeździe Królów. Ów „cichy boży murarz” nie widzi potrzeby uczestnictwa w tym święcie. Stosunek Kostki do parady idealnie odpowiada jego generalnej postawie wobec życia, którą cechuje wycofanie, zamknięcie się, unikanie jakiejkolwiek formy ideowego angażowania się.

$$
* \quad * \quad *
$$

Inteligentny, sprawnie zrealizowany, a mimo to banalny ${ }^{\prime \prime 51}$ - tak po pokazie Zartu Jaromila Jireša podczas Nowojorskiego Festiwalu Filmowego w 1969 r. ocenił film Vincent Canby. Recenzent „The New York Times" zarzucał Żartowi, że zbyt szybko odsłania przed widzem swoje główne przesłanie, jakim - zdaniem amerykańskiego krytyka - było ukazanie powolnej degradacji, gorzknienia, rosnącej hipokryzji wśród ludzi żyjących w stalinowskiej Czechosłowacji. To, co Canby'emu wydawało się „banalne”, w Czechosłowacji zostało odczytane jako odważna, otwarta krytyka zbrodni i wypaczeń związanych z dekadą lat 50. W konsekwencji po klęsce Praskiej Wiosny, odsunięciu od władzy Dubčeka i zaostrzeniu kursu politycznego, w 1971 r. Żart Jireša usunięto z dystrybucji oraz wymazano $\mathrm{z}$ oficjalnej filmografii reżysera ${ }^{52}$. Film ponownie znalazł się na ekranach w roku 1990.

W przywołanej już recenzji Vincent Canby odczytał Żart jako przypowieść o moralnej degrengoladzie ludzi żyjących w stalinowskiej Czechosłowacji. To bardzo celna interpretacja zarówno powieści, jak i filmu

51 V. Canby, The Joke (1969), „The New York Times” 18.09.1969, za: http://movies.nytimes. com/movie/review?res (dostęp: 26.01.2009).

52 Film nie zdążył dotrzeć na polskie ekrany; w polskiej prasie tego okresu nie znajdziemy żadnych recenzji Żartu. 
Żart. Uściślając, chodzi przede wszystkim o moralny upadek czechosłowackiego inteligenta. Trzej główni męscy protagoniści - niepogodzony ze sobą Ludvík, odnajdujący się w każdej sytuacji politycznej Zemánek oraz wycofujący się z aktywnego życia laborant Kostka - to właśnie przedstawiciele inteligencji. W takim ujęciu Żart staje się parabolą losów tej warstwy społecznej w latach 50., a także stawia diagnozę o kondycji tejże formacji w latach 60.

Niewątpliwie Żart jest jednym z najbardziej gorzkich filmów powstałych w latach 60. - ocena Kundery i Jireša dotycząca dwóch dekad powojennych cechuje się ostrym krytycyzmem i jest wyrazem zwątpienia, czy ci, którzy doświadczyli „piekielnej niemoralności" ${ }^{\prime 53}$ systemu komunistycznego, mogą w sobie zachować dobro, wiarę i prostotę, ludzkie odruchy. Żart jest wyrazem krytycznego stosunku względem nieudanych rozliczeń ze zbrodniami lat pięćdziesiątych. Okazuje się, że usłużni piewcy aktualnej władzy zawsze znajdą swoje miejsce w systemie.

Przedstawiona tu analiza filmu Żart może posłużyć również jako doskonała egzemplifikacja tego, w jaki sposób ideologia komunistyczna wykorzystała folklor i jego piewców. Pieśni i obrzędy ludowe zostały zawłaszczone przez nowy system, w którym przeznaczono im rolę politycznej agitki; ludowość, swojskość i tradycja stały się jedynie atrapami ustroju, który $\mathrm{w}$ folklorze widział szansę na zyskanie nowych zwolenników. Hasła, że z „muzyki ludowej wzejdzie nowy styl epoki”, że kluczowym zadaniem lokalnych patriotów jest zbudzenie do życia muzyki ludowej i zmuszenie jej, by dotrzymywała kroku współczesnej historii, okazały się utopią. Kundera gorzko puentuje klęskę Jaroslava, który całe swoje życie podporządkował realizacji owych szczytnych haseł: jego syn, zamiast przyjąć zaszczytną rolę króla w Jeździe Królów, pojechał do Brna na wyścigi motocyklowe, a koncert orkiestry dyrygowanej przez Jaroslava został zagłuszony wrzaskami pijących piwo wyrostków.

Ta obecna w powieści i filmie refleksja o zaanektowaniu dla swych celów przez komunistyczną władzę ideologii folkloru wzmacnia wizerunki i losy ich bohaterów. W powieści Kundery i filmie Jireša także Jazda Królów jest nie tylko tłem zdarzeń, które prowadzą do spotkania dawnych kolegów. W literackiej i filmowej narracji wątek Jazdy Królów, podobnie jak losów ludowej muzyki, pełni jeszcze jedną rolę - staje się gorzkim rozrachunkiem z komunistycznym systemem.

53 W recenzji filmu Agnieszki Holland Europa, Europa Kundera pisze o piekielnej niemoralności naszego stulecia, polegającej na tym, że człowiek postawiony jest w sytuacji, która nie pozwala na żadne moralnie zadowalające wyjście. Milan Kundera, Piekielna niemoralność, tłum. M. L., „Zeszyty Literackie” 1991, nr 34, s. 133-134. 